\title{
FUNGSI PEDESTRIAN JALAN TUNJUNGAN DARI SIRKULASI KE REKREASI: STUDI KASUS BERDASARKAN KESEJARAHAN
}

\author{
${ }^{1}$ OSWAN, Devina Benlin and ${ }^{2}$ ARIFIN, Liliany Sigit \\ ${ }^{1}$ Alumni Fakultas Teknik Sipil \& Perencanaan, Universitas Kristen Petra \\ Email:wind_reine@yahoo.co.id \\ ${ }^{2}$ Fakultas Teknik Sipil \& Perencanaan, Universitas Kristen Petra, Jl. Siwalanekrto 121-131, Surabaya 60236 \\ Email: lili@petra.ac.id
}

\begin{abstract}
ABSTRAK
Jalan Tunjungan sebagai salah satu pusat Kota Surabaya memiliki sebuah nilai historis dimana dahulu kawasan ini begitu hidup, tetapi seiring berjalannya waktu mengalami degradasi. Dari sekian banyaknya elemen-elemen pembentuk jalan ini, pedestrian-lah yang memegang peranan penting dan membutuhkan perhatian khusus. Melalui evaluasi ini akan dilakukan suatu peninjauan ulang terhadap Jalan Tunjungan abad 20 dan 21 berkenaan dengan hal-hal yang berdampak pada pedestrian seperti kendaraan bermotor, peneduh di pedestrian itu sendiri, aktivitas yang terjadi, jembatan penyebrangan, fasilitas-fasilitas pendukung, dan kriminalitas. Kesimpulan akhir menunjukkan bahwa akar masalahnya adalah penambahan kendaraan bermotor, serta ruang pedestrian yang tidak memadai.
\end{abstract}

Kata kunci: Jalan Tunjungan, pedestrian, kesejarahan, budaya.

\section{ABSTRACT}

Tunjungan street as one of Surabaya's downtown street has a historical value where this street used to be lively, but suffers degradation as time passes. Pedestrian, among other many elements, holds the most important role and claims extra attention. This evaluation will cover an observation of Tunjungan strret in $20^{\text {th }}$ and $21^{\text {st }}$ century concerning pedestrianimpacting elements such as automobiles, canopies in the pedestrian, the activities, overpass, supporting facilities, and crime. Conclusion shows that the root problem is the increase of automobiles and the insufficient spaces (narrow) for pedestrian.

Keywords: Tunjungan street, pedestrian, history, culture.

\section{PENDAHULUAN}

\section{Mlaku-Mlaku Nang Tunjungan}

'Rek ayo rek, mlaku-mlaku nang Tunjungan' adalah sebuah lagu yang mengajak arek-arek Suroboyo untuk menikmati Jalan Tunjungan di pusat kota yang dikenal terutama oleh focal point-nya yang sangat bersejarah, Mandarin Oriental Hotel Majapahit. Salah satu goresan pena sejarah yang paling membekas adalah menara bendera di Hotel Majapahit yang dulu disebut Oranje Hotel atau Hotel Yamato (zaman Jepang), dimana "Insiden perobekan bendera Merah-Putih-Biru terjadi, tepatnya pada tanggal 19 September 1945 pukul 10.30 pagi. Dari perobekan oleh pejuang-pejuang Surabaya maka berkibar-lah bendera Merah-Putih." ${ }^{[1]}$ Pada masa penjajahan Belanda, "kawasan elit di sepanjang jalan arteri mulai dari jalan Aloon-aloonstraat (Jl. Pahlawan), Jalan
Gemblongan, Jalan Toendjoengan, dan jalan Guvernur Suryo (Simpangweg) hingga pangkal jalan

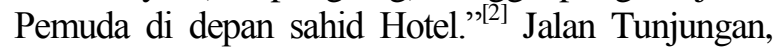
yang dahulu dikenal dengan nama Jalan Toendjoengan, memiliki sejarah panjang yang dapat ditarik hingga abad 19.

Kawasan Jalan Tunjungan tak pernah lekang oleh waktu, bahkan sampai akhir abad 20. Daerah ini telah menjadi pusat rekreasi yang dilengkapi berbagai Department Store seperti Siola di pertigaan Jalan Genteng Kali dan Jalan Tunjungan, berlanjut ke arah selatan jejeran toko antara lain Department Store Aurora, Sari Agung, Gading Murni, Bakso Tanjung Anom, dan Toko Kwang. Generasi terdahulu menikmati rekreasi 'mlaku-mlaku nang Tunjungan' bahkan mulai dari Jalan Basuki Rahmat (terdapat Toko Nam, Tunjungan Plaza, dan fasilitas ice-skating 'Go Skate'), berlanjut ke Jalan Praban (sepanjang jalan yang berjualan sepatu-sepatu bermerk), dan 
sampai ke Jalan Tunjungan. Dari Jalan Tunjungan, pengunjung dapat menyebrang kembali ke Jalan Basuki Rahmat.

Namun rekreasi semacam ini sudah tidak dapat lagi dinikmati di Jalan Tunjungan. Agaknya paradigma masyarakat sudah bergeser dari Surabaya kota sejarah, menjadi Surabaya kota metropolitan. Jalan Tunjungan yang dahulu adalah pusat rekreasi, kini tidak lebih dari sebuah jalan raya arteri yang dilalui mobil-mobil dari arah Jalan Genteng Kali, Jalan Praban, dan Jalan Gemblogan, yang ingin menuju ke Jalan Pemuda. Apa yang ditawarkan bagi para pendatang maupun warga Surabaya sendiri adalah mallmall bertingkat, seperti apa yang diutarakan Diane Dodd, "mempertahankan keuntungan maksimal dengan atraksi-atraksi ala kadarnya, menawarkan para pengunjung gairah yang murahan." ${ }^{[3]}$ Dengan tersedianya berbagai mall, kawasan ini ditinggalkan. Bahkan, boleh jadi daerah yang dulu disebut Kota Atas Bovenstaad pada zaman Belanda, yang mengimplikasikan keelitan kawasan ini, kini telah mati. Apa yang tersisa dari Bovenstaad itu hanyalah sebuah mall dengan empat bagian bernama Tunjungan Plaza. Pada zaman dulu, kata 'Tunjungan' akan ditangkap sebagai sebuah "jalan", tetapi kini nama itu ditangkap sebagai sebuah "plaza".

Jika dahulu arek-arek Suroboyo 'mlaku-mlaku nang Tunjungan', jalan-jalan ke Tunjungan, maka pertanyaannya sekarang bukanlah bagaimana arekarek Suroboyo zaman sekarang dapat 'mlaku-mlaku nang Tunjungan' lagi seperti masa lampau. Sebab, meskipun seseorang harus belajar dari sejarah, namun ia hendaknya tidak membawa masyarakat kepada masa lalu, tetapi harus tetap maju ke depan. Studi ini akan secara singkat membahas mengenai Jalan Tunjungan ditinjau dari perspektif kesejarahan. Elemen yang akan difokuskan adalah pedestrian atau area pejalan kaki, sebab di daerah yang sebenarnya lebarnya tidak lebih dari $30 \%$ lebar jalan raya inilah, pengunjung dapat sepenuhnya menikmati Jalan Tunjungan, bukan sekedar beberapa detik sekilas pandang dari jendela mobil. Dari sini diajukan pertanyaan: Tunjungan yang sekarang ini harus dibawa 'mlaku', berjalan kemana? Secara khusus, apa kelemahan pedestrian Jalan Tunjungan yang harus diperbaiki agar sesuai bagi arek-arek Suroboyo abad 21 ?

Kisho Kurokawa, seorang arsitek Jepang, gemar mengobrol dan makan bersama generasi muda untuk berdiskusi sambil berjalan dan menikmati keramaian kota. Kurokawa tidak menghabiskan waktunya

\footnotetext{
${ }^{3}$ Dodd, hal. 178
}

bersama generasi muda di Starbucks, seperti tradisi metropolitan zaman ini. Dimanakah lagi bisa disediakan tempat berdiskusi sambil menikmati keramaian kota selain beberapa meter lebar pedestrian yang memisahkan bangunan dari jalan raya? Diungkapkan Untermann, "salah sau bagian yang paling menyenangkan [di pedestrian] adalah adegan yang terus berganti dimana para penciptanya adalah pejalanpejalan kaki tersebut" ${ }^{\text {' }}$. Bahkan Rudofsky memberikan pernyataan yang lebih keras lagi, "Jika seseorang mengamati dunia literatur dalam theater, ia pada akhirnya akan menemukan dengan jelas bentuk peranannya yang seperti jalan.,[5]

Permasalahannya adalah, selain kehidupan metropolitan, individualisme juga telah menggerogoti mentalitas warga Surabaya. Kemunculan kendaraan bermotor dimotivasi dan sekaligus memberi warna kepada individualisme. "Dalam 40 tahun terakhir ini." Menurut Untermann, "sejak kendaraan bermotor telah menjadi trend domininan dalam transportasi, perencanaan kini difokuskan kepada kenyamanan kendaraan bermotor dan pengendaranya." ${ }^{,[6]}$ Akibatnya, sebuah laporan mancanegara mengabarkan bahwa "Pedestrian tetap merupakan satu-satunya hambatan terbesar lalu lintas." "[7] Tak heran Untermann kemudian menarik kesimpulan bahwa, "Kenyamanan dan keamanan pedestrian telah diabaikan di banyak daerah., ${ }^{,[8]}$

Begitu juga Pedestrian di Jalan Tunjungan merupakan faktor signifikan keberhasilannya menarik arek-arek Suroboyo, bukan hanya generasi abad 20 saja tetapi juga abad 21. Tujuan studi ini akan menggali potensi pedestrian ditinjau dari kacamata kesejarahan dan diharapkan akan dapat membawa Jalan Tunjungan kepada sebuah masa depan yang lebih baik. Bukan masa depan yang selamanya hidup dalam angan-angan masa lalu dan nostalgia, karena jalan ini bukanlah sebuah museum. Tetapi masa depan yang membangkitkan kembali 'mlaku-mlaku nang Tunjungan' tetapi dengan semangat abad 21 sebagai pusat rekreasi warga Surabaya beserta turisturisnya.

\section{Streets for the People}

Sebuah korelasi atau benang merah antara perancangan sebuah pedestrian dan kesejarahan dapat ditemukan melalui sebuah kata kunci yaitu kebudaya-

\footnotetext{
${ }^{4}$ Untermann, hal. 2

${ }^{5}$ Rudofsky, hal. 132

${ }^{6}$ Untermann, hal. 1

${ }^{7}$ Rudofsky, hal. 106

${ }^{8}$ Untermann, hal.1
} 
an atau 'culture', yang terpancar dalam suatu komunitas. Menurut John Urry, "[Masyarakat] sering mencurahkan pikirannya akan nostalgia untuk suatu tempat. Mereka akan mengungkapkan rasa kehilangan akan suatu 'rumah' karena perubahan sebuah budaya ekonomi maupun sosial",[9]. Pedestrian merupakan tempat dimana masyarakat atau komunitas pejalan kaki berkumpul dan melakukan sesuatu yang merupakan ciri khas kebudayaannya, yang mana pasti menimbulkan suatu sejarah. Bahkan, pedestrian itu sendiri adalah sebuah hasil kebudayaan. Hasil kebudayaan apapun dapat memberitahukan seseorang mengenai sejarah dari masyarakat di daerah tersebut, entah itu sejarah lima menit yang lalu, kemarin, tahun lalu, atau berdekade-dekade lalu. Oleh karena itu, tidak melulu pedestrian harus dilihat melalui kacamata sains ekologi maupun teknologi.

Dalam Streets for The People, Bernard Rudofsky memberikan tiga belas elemen dalam sebuah 'streets for the people', jalan untuk manusia. Ketiga belas elemen ini dijadikan empat belas bab dalam bukunya dengan judul yang dapat menggelitik rasa humor pembacanya. Keempat belas bab itu antara lain ialah: "Streets for pigs, Testimonials, The canopied street (serta lanjutannya, The canopied street, continued), Peripatetics, The street where the action is, What's in a name, In praise of stairs, Bridges and elevated streets, Mazes, Diamant street and crystal pavements, Fountainblues, The care and feeding of the pedestrian, crime does pay". Dalam paper ini, penulis memilih enam elemen dalam teori Rudofsky yang sesuai dengan keadaan Jalan Tunjungan, serta berhubungan dengan kesejarahan. Enam elemen itu antara lain:

Streets for pigs: "Penjajahan jalan oleh kendaraan bermotor pada masa kini dipraraelkan dengan penjajahan jalan oleh binatang pada masa lampau. Dengan usaha putus asa untuk membawa mereka keluar dari jalan, para hakim menetapkan suatu jasa tow-away (menggandengkan dan membawa pergi). ${ }^{[10]}$ Rudofsky mungkin mengungkapkannya dengan rasa antagonis terhadap perkembangan kendaraan bermotor. Namun, perbandingan Rudofsky di satu sisi menyebabkan bahwa masa ini berarti lebih bodoh ketimbang masa lalu. Setidaknya, zaman dahulu orang masih berpikir untuk menyingkirkan binatang-binatang ini. Di masa ini, justru pengendara kendaraan bermotor yang adalah mayoritas-lah yang ingin mengusir pejalan kaki.

\footnotetext{
${ }^{9}$ Urry, hal. 172

${ }^{10}$ Rudofsky, hal. 45
}

Menurut Untermann, "Pedestrian kini hanya nyaman di pulau-pulau kecil pedestrian yang dikelilingi kendaraan bermotor." ${ }^{[11]}$ Padahal, "Untuk pengendara kendaraan bermotor, jalan raya hanyalah sebuah perantara, namun untuk pejalan kaki, jalan itu adalah suatu pengalaman tersendiri." ${ }^{[12]} \mathrm{Di}$ dalam buku yang sama, ia menawarkan kriteria desain yang memicu pelayakan dan pemakaian pedestrian bagi pejalan kaki: Safety, Covenience, dan Pleasure. Pertama, Safety atau keamanan dari kendaraan bermotor yang berada di jalan raya. Angka kecelakaan di Surabaya yang tinggi menunjukkan bahwa ini bukan barang baru.

Kedua, Convenience atau kontinuitas serta kenyamanan dalam berjalan kaki. Kenyamanan dipengaruhi oleh hambatan yang terdapat di suatu jalan, serta berapa jauhnya jarak dapat ditempuh seseorang. Ketiga adalah, Pleasure atau kesenangan, yaitu seberapa menarik sebuah pedestrian menjadi pengalaman pejalan kaki. Hal yang paling sederhana misalnya dari objek yang dapat dilihat di jalan tersebut. Sebuah jalan dengan yang dilalui dengan kecepatan 3MPH (pejalanan kaki) dan $40 \mathrm{MPH}$ (kendaraan bermotor) tentu memiliki kualitas pleasure yang berbeda. Pengendara bermotor tidak memperhatikan detail dan cukup dengan desain yang serba minimalis. Pejalan kaki membutuhkan sesuatu untuk menghilangkan kebosanan kala berjalan. Jalan Tunjungan yang memiliki nilai historis tinggi, serta fokus studi yang adalah kesejarahan akan menekankan pada aspek pleasure ini.

The canopied street: "Aspek sosial dari sebuah portico adalah sama pentingnya dengan aspek klimatisnya." ${ }^{[13]}$ Demikian menurut Rudofsky. Rudofsky sendiri bahkan membagi dua istilah antara portico dengan arcade. Namun, apapun istilahnya, tetap tidak mengurangi kepentingan sebuah peneduhan pada pedestrian. Pedestrian yang baik hendaknya dilengkapi peneduhan, bukan hanya untuk alasan sains dan iklim saja, tetapi juga menyangkut masalah sosial.

Semua orang tentu mengerti bahwa setiap negara secara unik memiliki peneduhan yang sesuai dengan iklim masing-masing. Namun, jarang diperhatikan bahwa bentuk sebuah peneduhan juga merupakan hasil sejarah dan budaya. Oleh karena itu, dilihat dari kacamata kesejarahan dan kebudayaan, sebuah peneduhan hendaknya memicu terjadinya sebuah interaksi sosial ditinjau dari dua dimensi: vertikal dan horisontal.

\footnotetext{
${ }^{11}$ Untermann, hal. 1

${ }^{12}$ Ibid., hal. 15

${ }^{13}$ Rudofsky, hal. 74
} 
Dari segi dimensi vertikal, Rudofsky mengungkapkan "Ada banyak beranda dan piazzas (plaza) di dalam kota, yang nyaman untuk melindungi orang dari hujan, tetapi membuat jalan menjadi sempit dan gelap." ${ }^{,[14]}$ Kelemahan desain sebuah peneduhan, baik berupa portico, arcade, beranda, dan sebagainya, adalah kecenderungannya untuk memberikan kesan menekan manakala langit-langitnya terlalu rendah dan tidak skalatis dengan manusia yang lewat di bawahnya.

Dari segi dimensi horisontal, suatu peneduhan akan membentuk bayang-bayang di bawahnya, dimana bayang-bayang ini sendiri menciptakan sebuah ruang dalam dimensi horisontal. Harus disadari bahwa dalam sebuah pedestrian, ada lebih dari satu orang yang melaluinya dimana orang-orang ini memiliki personal space sendiri-sendiri. Menurut Hall, "setiap orang dilingkupi oleh empat ruang 'gelembung' yang tak kasat mata: intim, personal, sosial, dan publik (Gambar 1).

Jarak intim adalah jarak ketika berpelukan, bersentukan, atau berbisik. Jarak pribadi adalah jarak interaksi dengan kawan akrab atau keluarga. Jarak sosial adalah jarak interaksi dengan rekan atau kenalan, sementara jarak publik adalah interaksi lain seperti public-speaking." ${ }^{,[5]}$ Tergantung fungsi spesifik sebuah pedestrian, jarak-jarak ini tidak boleh lebih besar daripada luasan ruang yang terbentuk di bawah peneduhan. Sebuah peneduhan harus memiliki cukup ruang untuk menampung semua orang, berikut dengan personal space yang mereka bawa masingmasing.

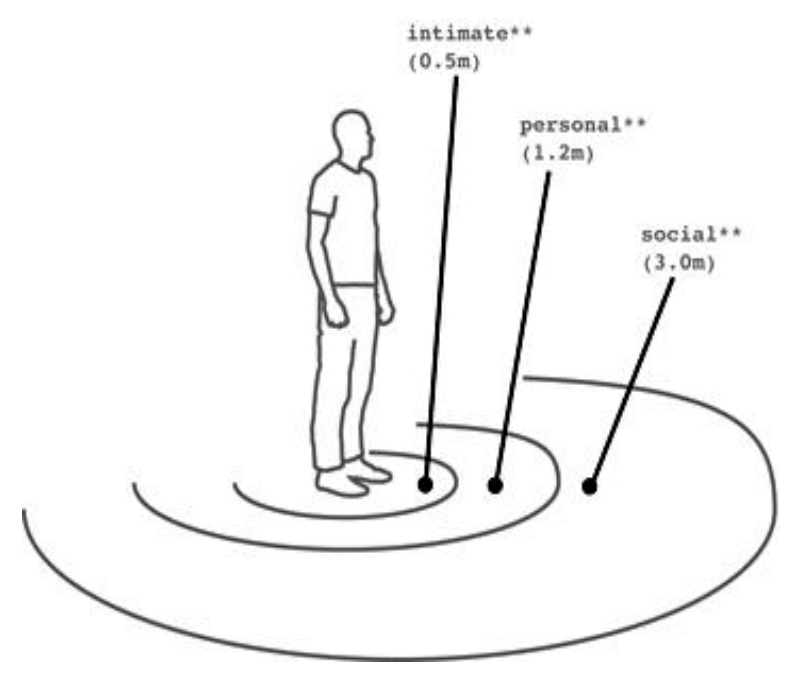

Gambar 1. Personal Ruang
The street where the action is: Bernard Tschumi, dalam Manhattan Transcrip, menyatakan bahwa keberanekaragaman definisi arsitektur - ruang (space), aksi (action), dan pergerakan (movement) menghasilkan arsitektur tersebut sebuah event, sebuah tempat penuh kejutan, sebuah tempat penemuan diri sendiri. ${ }^{[16]}$ Tak dapat dipungkiri bahwa pedestrian yang merupakan sebuah karya arsitektur tak lepas dari konsep ini. Sebuah pedestrian di zaman sekarang ini hanya dian*ggap sebagai pergerakan (movement) saja, dimana orang berpindah dari satu tempat ke tempat yang lain. Di poin sebelumnya telah dibahas sebuah pedestrian, lengkap dengan peneduhannya, akan menciptakan sebuah ruang (space) yang harus dapat menampung bukan hanya manusia tetapi juga personal space masing-masing. 'The street where the action is' menambahkan sebuah elemen lagi di dalam pedestrian, yakni sebuah aksi (action) yang terjadi di dalamnya.

Inilah yang akhirnya dapat menciptakan sebuah jalan sebagai tempat yang dapat dinikmati oleh Kisho Kurokawa sebagai sebuah 'keramaian kota'. Duduk di sebuah pedestrian sambil melihat orang berlalulalang dan beraktivitas tidak hanya memicu interaksi sosial yang telah membeku di zaman serba individualis ini, tetapi juga sangat menyenangkan. Menurut Rudofsky, "sebelum aksi dan emosi manusia dipamerkan di panggung dengan dibayar, jalan itu sendiri telah merupakan sebuah teater besar berskala dunia." $"[17]$

Bridges and elevated streets: Jembatan penyeberangan untuk pejalan kaki sebenarnya bukanlah hal baru di masa kini. Menurut Rudofsky "pada waktu ketika menunggang kuda merupakan jalan tercepat untuk sampai ke suatu tempat, Leonardo [Da Vinci] memberikan pemikiran tentang transportasi yang cepat di masa depan. Untuk membuat sebuah lalu lintas kota efisien dan menyenangkan untuk semua, ia merencanakan sistem ganda pada jalan-jalan arteri dengan ketinggian tanah untuk kendaraan jenis

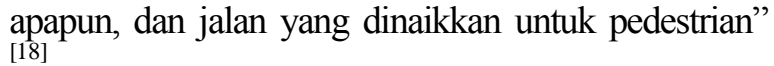

Namun, Untermann tidak memandang baik ide ini. Menurutnya, "penggunaan yang berlebihan pada jembatan penyebrangan dapat menyebabkan pejalan kaki mening-galkan jalan di bawah, dan menurutnkan kualitas jalan. Jalan tersebut akan menjadi makin berbahaya dan tidak menyenangkan bagi mereka

\footnotetext{
16 "Bernard Tschumi-Six Concepts: Excerpt from Architecture and Disjunction"

${ }^{17}$ Rudofsky, hal. 123

${ }^{18}$ Ibid., hal. 188

Ibid., hal. 188
}

\footnotetext{
${ }^{14}$ Ibid., hal. 79

${ }^{15}$ Fridman, hal. 10
} 
yang terpaksa harus berjalan di sana., ${ }^{,[19]}$ Selain itu, dari segi kenyamanan, "dibutuhkan sembilan kali lebih banyak energi untuk mendaki dan melalui jembatan penyebrangan dibandingkan menyebrang dengan ketinggian yang sama.,"[20]

Untuk itu, "sebuah jembatan yang menghubungkan dua bangunan utama, dimana pejalan kaki mendaki sebagai bagian dari rute normalnya (seperti ramp) atau elevasi natural yang mengizinkan pengguna untuk mencapainya tanpa perlu menggunakan tangga, akan memberikan keuntungan bagi pejalan kaki."[21]

The care and feeding of the pedestrian: Menurut Rudofsky, "sebuah cafee yang otentik akan menjadi bagian dari sebuah jalan, trotoar atau bukan. [...] Ia merepresentasikan versi statis dari sebuah perjalanan-dapat dikatakan sebuah 'stasiun' pejalan kaki. ${ }^{, 22]}$ Sebuah cafe, atau minimal vendor kecilkecilan, akan memberikan fasilitas kepada para pejalanan kaki yang mungkin kehausan atau lapar di tengah perjalanan. Bahkan semisalkan tidak lapar atau tidak haus pun, tempat-tempat ini akan memicu terjadinya kegiatan ekonomi yang membuat sebuah pedestrian makin hidup. Di beberapa daerah Eropa, misalnya di Roma, sebuah jalan yang minim trotoar, tiang listrik, apalagi kendaraan dijadikan tempat yang sempurna untuk makan malam outdoor pada musim panas. Pencahayaannya tidak melulu dari lilin, tetapi juga bulan purnama di musim panas serta lenteralentera yang digantung di atas jalan.

Perlu digaris bawahi bahwa 'the care and feeding of the pedestrian' tidak berbicara tentang tempat makan saja. Bahasa yang digunakan Rudofsky, 'stasiun' pejalan kaki, juga mengindikasikan kebutuhan lain yang dibutuhkan seorang pejalan kaki selain makan. Kebutuhan itu adalah beristirahat. Menurut Untermann, "Pejalan kaki yang membawa barang belanjaan atau mengasuh anak lebih peka terhadap waktu dan jarak dan tidak akan mau berjalan lebih dari 1000 kaki., ${ }^{,[23]}$ Oleh karena itu, ada baiknya disediakan tempat-tempat perhentian seperti "penyediaan troley belanja, locker, atau check-in point untuk menyimpan barang belanjaan dan suatu jasa pengiriman rendah biaya yang memungkinkan shopping yang lama tanpa dibebani barang belanjaan."[24]
Crime does pay: Salah satu kriminalitas yang paling terlihat adalah vandalisme. Vandalisme merupakan kriminalitas yang lebih jahat dibandingkan pencurian. Seorang pencuri tahu nilai sebuah barang dan mengharaginya, oleh sebab itu ia mengambilnya dari orang lain karena ingin memilikinya. Tetapi vandalisme adalah pengerusakan sebuah properti yang dimiliki orang lain. Ini berarti pelakunya bahkan tidak menghargai nilai dari suatu barang. Hal yang sama terjadi juga di dalam pedestrian. Menurut Rudofsky, "Vandalisme selalu menjadi pengeluaran tenaga terbesar dari negara, bukan hanya karena masalah memecahkan jendela dan merusak fasad bangunan, tetapi juga untuk kerusakan berskala besar yang pada akhirnya harus membawa kepada pembaharuan kota secara keseluruhan." ${ }^{[25]}$

Masalah keamanan di pedestrian memang masalah yang pelik. Untuk membuat suatu kawasan yang nyaman dan aman dilalui pejalan kaki, terlebih dahulu harus dipastikan agar pedestrian tersebut bebas dari kriminalitas dan pihak-pihak yang tidak bertanggung jawab. Namun, Untermann justru mengatakan bahwa pejalan kaki-lah yang dapat sadar pada kehadiran orang-orang luar dan mendeteksi keanehan seperti vandalisme, perampokan, dan penjabalan. ${ }^{[26]}$ Ini merupakan suatu problem sirkuler sebab agar sebuah jalan dapat dilalui orang, jalan tersebut harus aman. Tetapi keamanan suatu jalan tergantung dari apakah orang tertarik untuk melaluinya atau tidak.

\section{METODOLOGI}

Studi ini merupakan penelitian kualitatif yang memakai metode eksploratif. Langkah-langkah penelitian dimulai dengan merekam kondisi eksisting pada pagi, siang, dan malam hari, serta dilengkapi dengan studi literatur, internet, dan wawancara dengan generasi terdahulu khususnya untuk pengumpulan informasi mengenai Jalan Tunjungan abad 20. Dari keadaan tersebut dilakukan analisa dengan SWOT (strength, weakness, opportunity, thread) untuk mencari keunggulan dan kelemahan serta potensi yang dapat dikembangkan atau dihindari. Langkah selanjutnya dengan kerangka teori yang dibahas dalam tinjauan pustaka, maka diberikan sebuah pemikiran dari kacamata kesejarahan (Gambar 2).

\footnotetext{
${ }^{19}$ Untermann, hal. 37

${ }^{20}$ Ibid.

${ }^{21}$ Ibid., hal. 38

${ }^{22}$ Rudofsky, hal. 308

${ }^{23}$ Untermann, hal. 24

${ }^{24}$ Ibid., hal. 68
}

${ }^{25}$ Rudofsky, hal. 331
${ }^{26}$ Untermann, hal. 3 


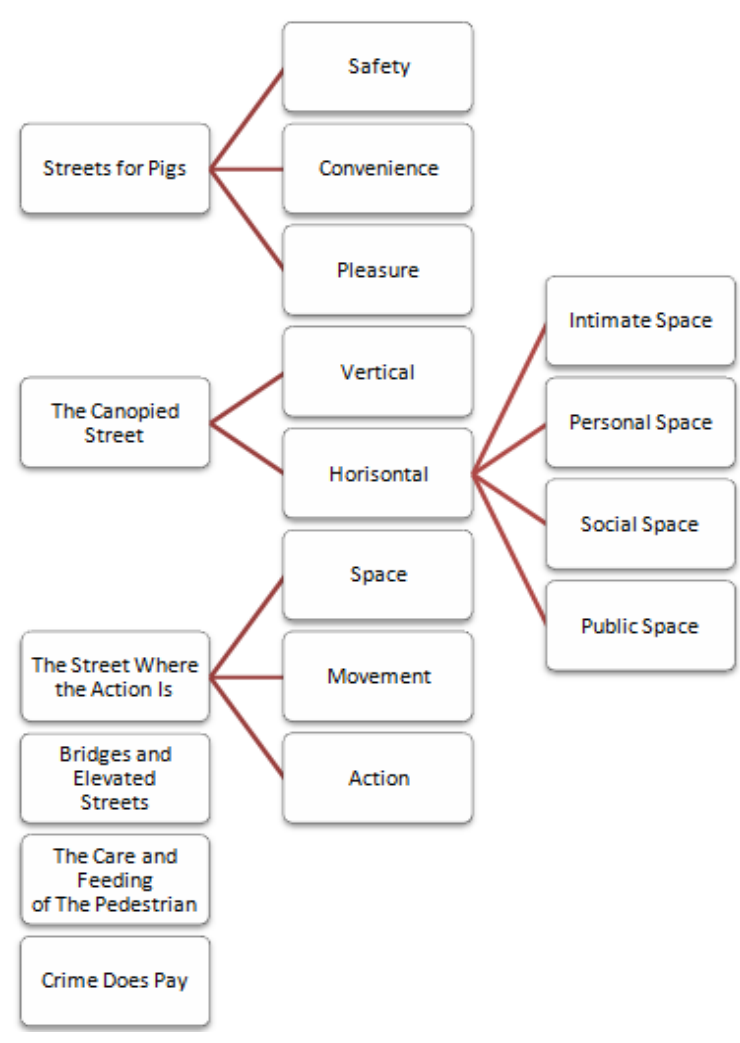

Gambar 2. Kerangka Berpikir

\section{KONDISI EKSISTING}

Area yang dijadikan bahan studi adalah Jalan Tunjungan yang terletak di pusat kota Surabaya (Gambar 3A), mulai dari perempatan dengan Jalan Genteng Kali, Jalan Praban, dan Jalan Gemblongan, dan berakhir di selatan di Hotel Majapahit (Gambar 3B). Jalan raya dilalui kendaraan satu arah dari arah utara, mengakibatkan bottle-neck effect akibat bermuaranya tiga jalan ke satu jalan Tunjungan. Pedestrian berada di kedua sisi jalan dengan lebar rata-rata 3 meter (Gambar 3C).

\section{JALAN TUNJUNGAN: JALAN UNTUK MANUSIA}

Hasil penelitian akan dipaparkan berdasarkan keenam elemen jalan untuk manusia menurut Rudfosky.

\section{Street for Pigs}

Pada tahun 1900an, Jalan Tunjungan memiliki pedestrian yang relatif lebih sempit dengan jalan raya dibandingkan sekarang. Tidak hanya itu, lebar pedestrian pun tidak lebih lebar daripada sekarang. Namun, justru tahun-tahun inilah masa kejayaannya Jalan Tunjungan. Kini, tidak peduli seberapapun pedestrian dilebarkan, tetap tidak banyak pejalanan kaki yang jewat di jalan yang sudah disediakan.

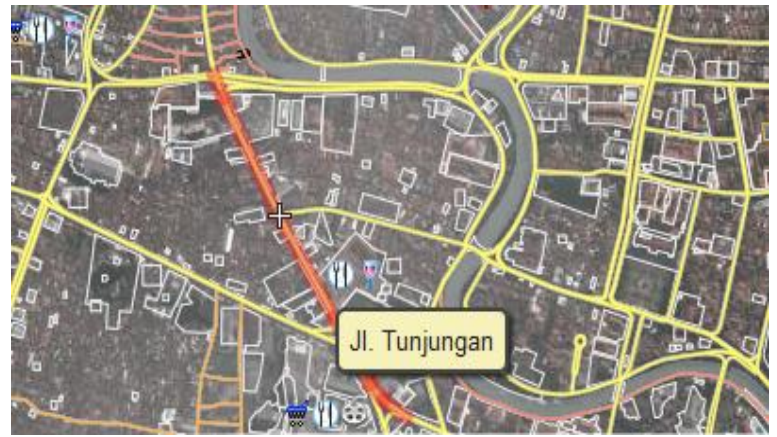

(A)

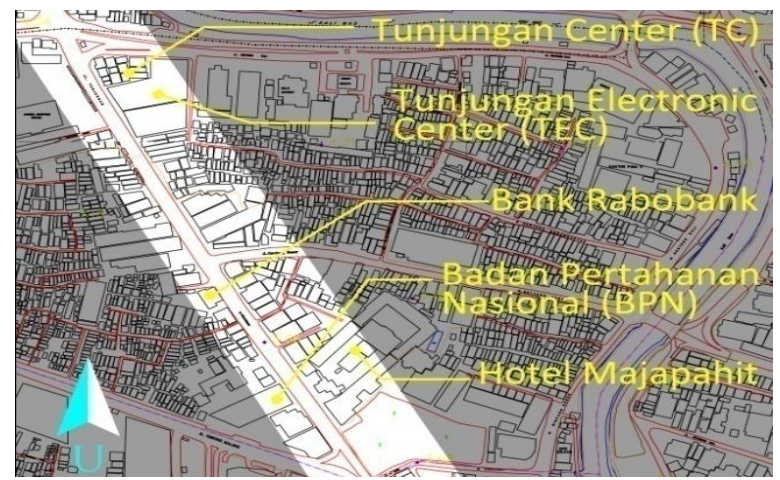

(B)

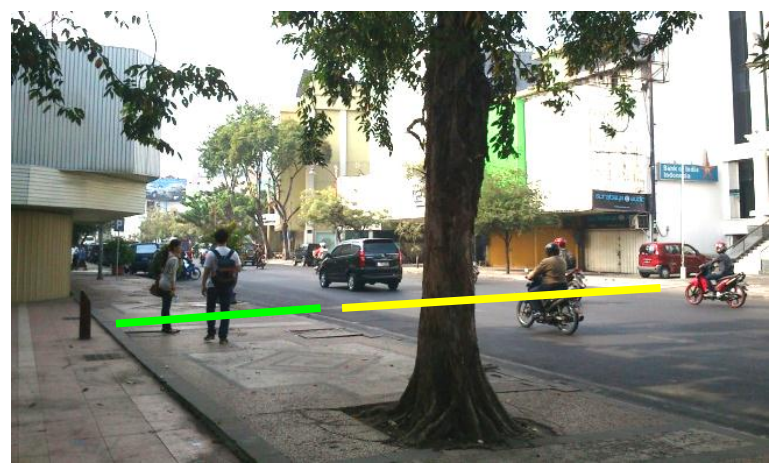

(C)

Gambar 3. Kondisi Obyek Penelitian A, B, \& C

Jika diteliti, ini disebabkan karena pada masa lampau volume kendaraan relatif lebih sedikit. Begitu sedikitnya jumlah kendaraan bermotor, sampaisampai becak dan sepeda pun dapat berjalan berdampingan dengan mobil di jalan raya. Tidak ada suatu upaya untuk memisahkan antara kendaraan bermotor, sepeda, dan pejalan kaki. Salah satu hal yang lain adalah ketiadaan sepeda motor di Jalan Tunjungan masa lampau.

Selain masalah volume kendaraan bermotor, yang juga perlu mendapat perhatian adalah kecepatan kendaraan yang melalui Jalan Tunjungan. Kecepatan maksimal mobil klasik adalah sekitar 60 kilometer per jam. Kini, kecepatan mobil maksimalmencapai 200 kilometer per jam, tentu akan sangat membahayakan keselamatan pejalan kaki. 
Volume dan kecepatan kendaraan yang berbeda di abad 20 dan abad 21 pada Jalan Tunjungan tentu akan sangat mempengaru-hi ketiga poin yang disebutkan Untermann: Safety, Convenience, dan Pleasure. Dari segi safety, seperti yang dituliskan dalam 'Remaking Minnie Street', "mengurangi volume dan kecepatan kendaraan adalah kunci dalam meningkatkan keselamatan pedestrian untuk segala usia." $"[27]$

Kedua, convenience atau kenyamanan. Di sepanjang sisi pedestrian Jalan Tunjungan, baik sisi timur maupun barat, padat diparkiri kendaraan (Gambar 4), khususnya sepeda motor yang tidak hanya sembarang parkir di daerah pedestrian, tetapi bahkan melewati pedestrian (Gambar 5). Pada pedestrian di sisi barat, mobil ikut parkir di area pejalan kaki. Di sisi sebelah timur, terdapat tempat parkir sepeda motor di dalam gedung dan parkiran mobil untuk pusat perbelanjaan TC dan TEC yang berada di basement. Menurut Untermann, hal-hal semacam ini "harus dilarang pada jalanan umum. [...] Drive-in menciptakan bahaya ketika kendaraan masuk keluar, mengganggu kontinuitas jalan, dan secara visual mengurangi keindahan daerah pejalan kaki. ${ }^{,[28]}$ Maka, nampak sangat jelas sekali bahwa ini sangat merusak pedestrian di Jalan Tunjungan.

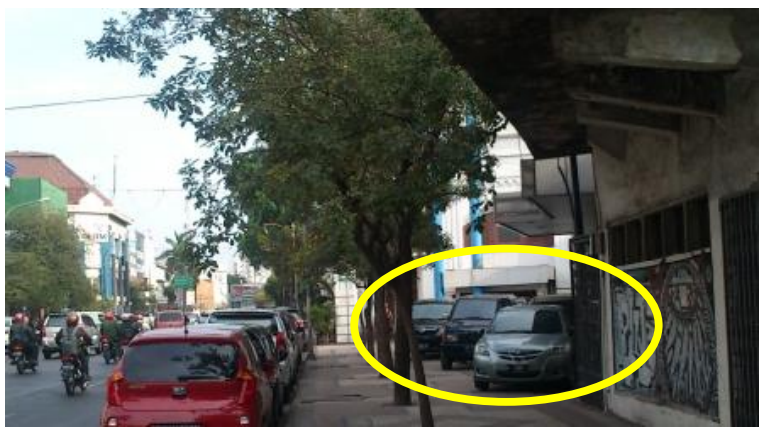

Gambar 4. Kondisi Pedestrian Jalan Tunjungan Sekarang

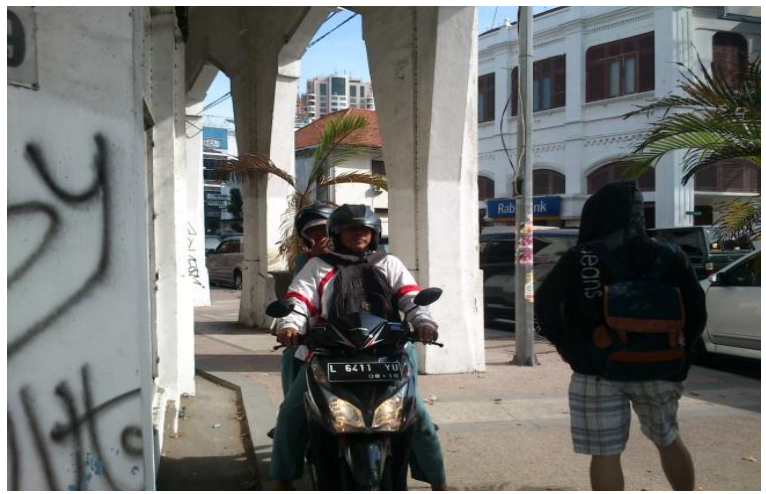

Gambar 5. Pedestrian menjadi Jalan Raya

\footnotetext{
${ }^{27}$ Day, hal. 315

${ }^{28}$ Untermann, hal. 12
}

Ketiga, pleasure. Menurut Untermann, "Arsitek telah merespon terhadap kendaraan bermotor dengan menyederhana-kan bangunan dan lingkungan. Tokotoko telah menjadi lebih panjang tanpa dekorasi atau jendela, dengan tanda yang helas dan besar agar jelas terlihat dari jalan raya. Display jendela dan pohon hilang. Jalan yang telah direstruktur ini disederhanakan berdasarkan kecepatan mobil, yang mana merugikan mereka yang berjalan kaki." ${ }^{[29]}$ Ini dikarenakan, "Tiga puluh mil per jam telah menggantikan tiga mil per jam sebagai kecepatan baru dimana arsitek dan insinyur mengevaluasi bangunan mereka." ${ }^{\text {,[30] }}$

Di Jalan Tunjungan sendiri, pada abad 20an masih dipenuhi dengan bangunan-bangunan style kolonial Belanda. Style ini bisa berupa art deco, art nouvo, dan sebagainya, mengikuti kaidah-kaidah estetika arsitektur modernisme seperti komposisi repetisi, irama, hierarki, dan sebagainya dalam perancangannya. Ditambah lagi, dengan minimnya kendaraan bermotor, dan jika adapun kecepatannya sangat rendah, maka spanduk-spanduk dan billboard berukuran besar sangat tidak diperlukan. Jalan Tunjungan abad 20, jika dibandingkan dengan sekarang, terasa sangat lapang dan lega (Gambar 6). Kini, dengan banyaknya billboard, khususnya billboard yang menutupi keindahan bangunan style kuno Rabo Bank, menyebabkan suatu degradasi keindahan Jalan Tunjungan bagi para pejalan kaki.

Volume dan kecepatan mobil perlu diperhatikan secara khusus. Namun, tidak perlu mengambil langkah yang terlalu ekstrem seperti penutupan Jalan Tunjungan sepenuhnya yang dulu sempat pernah akan dilakukan. ${ }^{[31]}$ Langkah yang terbaik untuk saat ini adalah pengurangan volume kendaraan dan kecepatan yang diizinkan, misalnya dengan pelebaran pedestrian. Pada saat yang sama, kualitas visual Jalan Tunjungan juga harus diperhatikan dengan cara menyingkirkan billboard-billboard dan display tokotoko yang lebih atraktif.

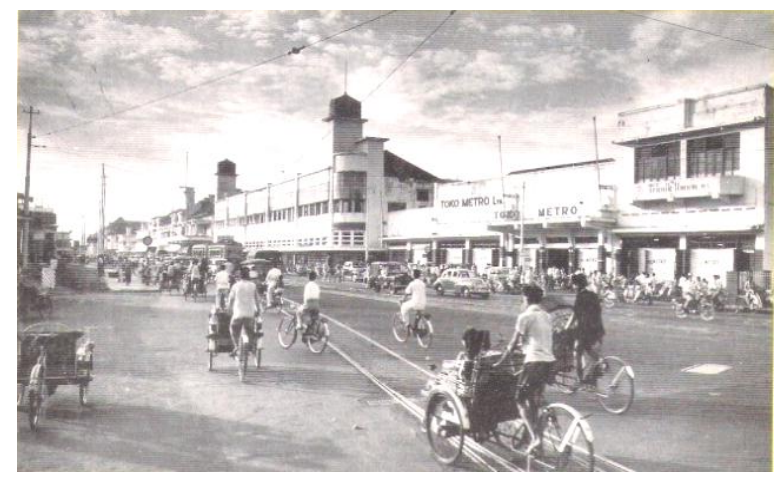

Gambar 6. Kondisi Jalan Tunjungan Abad 20

\footnotetext{
${ }^{29}$ Ibid., hal. 16

${ }^{30}$ Ibid.

${ }^{31}$ Silas, hal. 84-91
} 


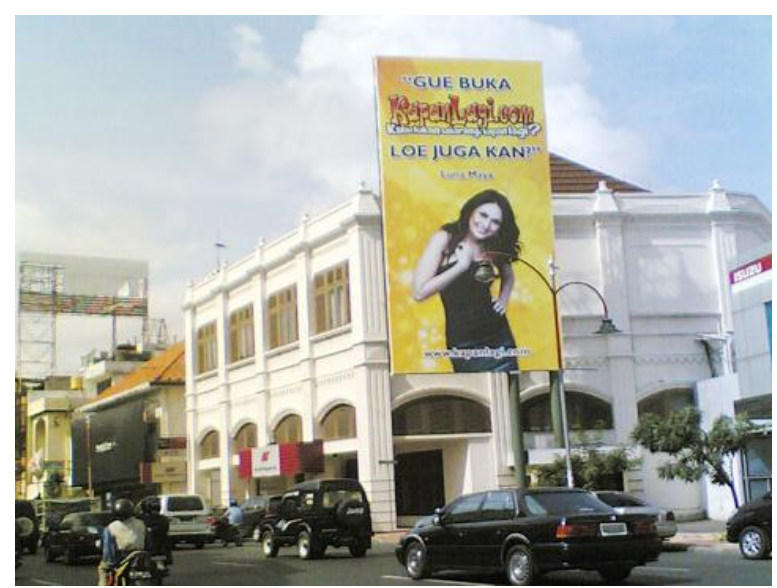

Gambar 7. Kondisi Papan Reklame Sepanjang Jalan Tunjungan Abad 21

\section{The Canopied Street}

Keadaan peneduh-peneduh di pedestrian Jalan Tunjungan boleh dikatakan memperihatinkan, kalau bukan sangat menyedihkan. Secara estetika, sekilas pandang saja terlihat bahwa peneduh-peneduh yang berbentuk arcade ini tidak dirawat dengan baik dan menjadi objek vandalisme tangan-tangan yang tidak bertanggung jawab. Selain itu, ukuran kolom-kolom sangat besar (Gambar 8 \& 9). Di arcade Tunjungan Center (TC), kolom-kolomnya kurang lebih berukuran $100 \times 80 \mathrm{~cm}$. Kolom-kolom ini dapat dipakai penjambret bersembunyi, yang pada akhirnya menimbulkan rasa tidak aman.

Jika dilihat dari segi vertikalnya, tentu dapat terlihat sebuah perbedaan mencolok. Misalnya, di bangunan TC yang dulu bernama Siola, dan pada penjajahan Belanda dinamakan Engelsche Warenhuis.

Semakin lama, dimensi vertikal arcade ini mengalami pengurangan. Engelsche Warenhuis memiliki arcade yang sangat tinggi, menurut perkiraan dari foto mungkin hampir empat kali tinggi manusia (Gambar 10).

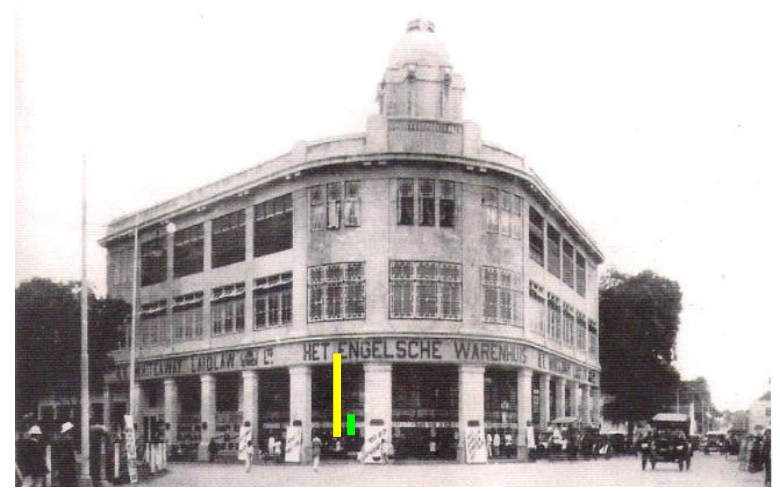

Gambar 8. Bangunan Siola Tempo Dulu

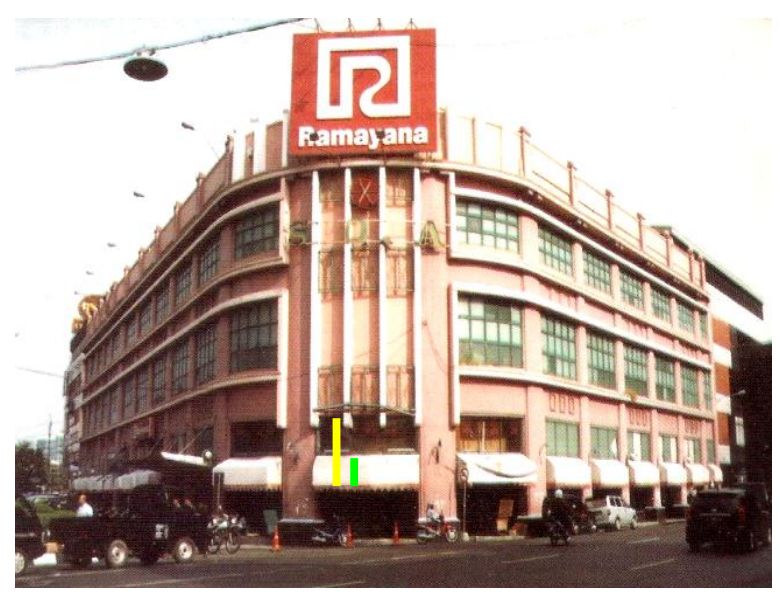

Gambar 9. Bangunan Siola (Tujungan Center) Sekarang

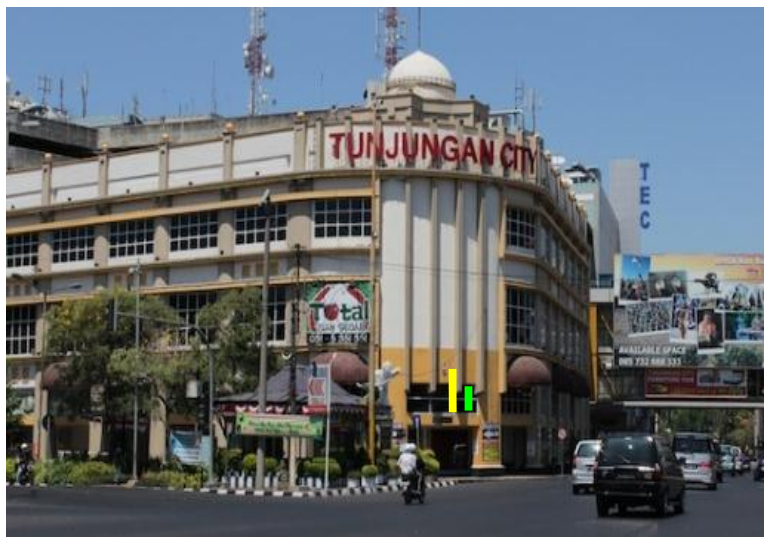

Gambar 10. Skala Pilar Arcade Siola dg Manusia: : Ketinggian langit-langit arcade
:Skala manusia

Arcade yang tiggi tidak hanya baik untuk iklim tropis Surabaya saja, tetapi pada saat yang sama arcade-arcade yang tinggi dapat mengurangi kesan sempit dan tertekan. Pada siang hari, arcade-arcade yang terlalu rendah akan memberikan kesan suram dan menghalangi cahaya matahari ke pedestrian, apalagi masuk ke dalam bangunan.

Sementara untuk dimensi horisontal, Edward T. White telah memberikan sebuah diagram mengenai detail radius personal space yang diperolehnya melalui survey pada orang-orang Amerika. Masalahnya, menurut Hall sendiri terdapat dua tipe budaya, contact culture dan noncontact culture. Indonesia, yang berada di Asia Tenggara termasuk noncontact culture, yang sedikit bersentuhan, memposisikan diri jauh satu dengan yang lain, berhadapan dengan tidak langsung, dan mempertahan-kan tatapan mata lebih sebentar daripada negara-negara contact culture. ${ }^{[32]}$

\footnotetext{
${ }^{32}$ Griffin, hal. 64
} 
Jelas sekali bahwa diagram ini sebenarnya kurang memadai untuk kondisi di Indonesia, tepatnya Surabaya. Warga Surabaya tentu memiliki personal space yang radiusnya lebih besar daripada diagram White yang ia temukan berdasarkan surverynya dengan orang-orang Amerika. Namun untuk suatu angka minimal, digunakan diagram ini.

Ketika berjalan dengan seorang teman atau keluarga, jarak yang digunakan adalah personal space, yaitu sekitar 46 sampai $122 \mathrm{~cm}$. Sementara dengan orang yang tidak dikenal menggunakan social space, jaraknya bertambah yaitu sekitar 1,2 sampai 2,4 meter. Ukuran pedestrian rataratanya tidak sampai tiga meter. Ini berarti, pejalan kaki dalam satu kelompok teman atau keluarga hanya bisa berjejer tiga sampai empat orang. Dan jika tidak saling mengenal, kemungkinan besar hanya bisa dua orang saja. Jika berpapasan dari arah berlawan dan tidak saling mengenal, maka terpaksa orang harus berjalan beriringan. Tentu saja ini sangat tidak memadai untuk sebuah pedestrian.

Dibandingkan dengan keadaan Jalan Tunjungan pada abad 20, sebenarnya tidak terlalu berbeda jauh. Malah, pada tahun 1930an sampai 1950an, bangunanbangunan hampir tidak memiliki arcade, melainkan hanya tenda-tenda kanopi kecil (Gambar 11).

Bagaimana, dengan tanpa arcade melainkan hanya peneduhan berupa tenda kanopi kecil ini, memungkinkan penampungan para pejalan kaki dengan seluruh personal space nya masing-masing? Ada dua alasan. Pertama, perlu dingat bahwa kanopikanopi berbentuk tenda ini, meski berukuran kecil, tetapi tidak dilengkapi kolom-kolom besar yang sifatnya membatasi ruang yang terbentuk di dalamnya. Ketiadaan kolom ini mengizinkan ruang tak terbatas, yang juga didukung dengan minimnya kendaraan bermotor di Jalan Tunjungan, menyebabkan kesan yang sangat lega bagi penajalan kaki.

Alasan kedua adalah, tidak selamanya Indonesia dapat dikategorikan sebagai negara yang noncontact culture. Pada abad 20, sebelum wabah-wabah individualisme menyerang Asia Tenggara, Indonesia adalah negara yang masyarakatnya relatif lebih ramah dan lebih mudah bersosialisasi daripada negaranegara Asia Tenggara lain seperti misalnya Singapura atau Malaysia. Sebagai buktinya, di Indonesia orangorang dapat duduk berdesak-desakkan di bemo dan percakapan mudah terjadi dengan supirnya, bahkan orang yang tidak dikenal sekalipun. Dibandingkan negara lain, misalnya Tiongkok dan Singapura, meskipun bis dan kendaraan umum di sana sangat penuh, jarang sekali terjadi percakapan antara satu orang dengan orang yang lain. Pembayaran angkutan umum bahkan terjadi tanpa kontak mata. Ini berarti, warga Surabaya abad 20 membutuhkan personal space yang tidak seluas abad 21 ini.

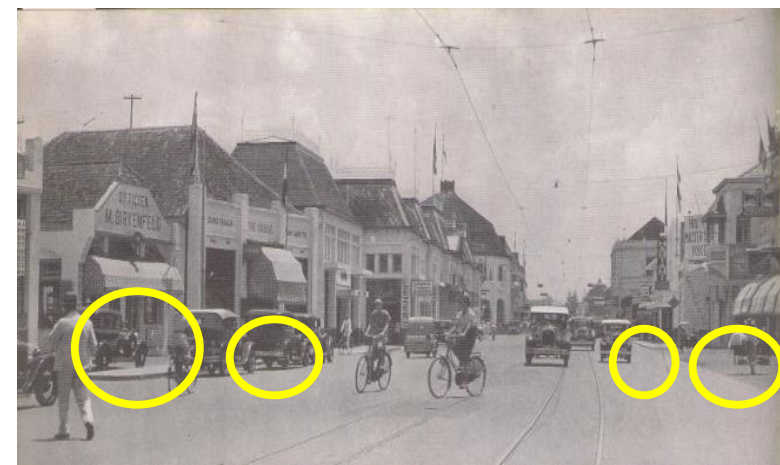

Gambar 11. Canopy Arcade Tunjunan Tempo Dulu

Pada akhirnya, perlu diperhatikan apakah luasan pedestrian yang 'dipagari' dengan kolom ini perlu diperluas atau tidak, apakah arcade-arcadenya perlu penambahan dimensi baik horisontal maupun vertikal. Kedua, secara kreatif perlu dipikirkan suatu solusi untuk memanfaatkan kolom-kolom ini untuk membangkitkan suatu 'budaya' masyarakat.

\section{The Street Where the Action Is}

Jika diperhatikan pada masa kini, tidak ada orang yang memiliki waktu untuk duduk-duduk sambil memandangi orang berlalu-lalang, apalagi di sebuah pedestrian yang kenyamanannya patut dipertanyakan seperti Jalan Tunjungan. Karena itu, fungsi Jalan Tunjungan hanya sebagai sirkulasi saja, sebuah movement yang memungkinkan pejalan kaki untuk secepatnya meninggal-kan pedestrian tersebut dan mencapai tujuan tanpa suatu pengalaman yang berkesan. Inilah yang pada akhirnya menimbulkan kejemuan. Makin menjemukan sebuah pedestrian, makin besar tendensi jalan tersebut untuk dipakai sebagai movement saja. Dan pada saat yang sama, semakin sering sebuah jalan dipakai untuk movement saja, semakin menjemukan pedestrian tersebut. Problematika sirkuler dan rumit seperti inilah yang sulit dipecahkan.

Jalan Tunjungan pada abad 20an memenuhi semua kriteria place yang didalamnya terdapat event, yaitu tidak hanya space dan movement saja, tetapi juga action. Ada space yang sangat memadai untuk menampung pejalan kaki beserta personal space mereka masing-masing, yang pada masa itu masih tidak seluas sekarang. Space ini memungkinkan sebuah movement, yaitu sebuah pergerakan yang bebas dan lega. Apalagi, waktu itu kendaraan bermotor tidak sembarangan diparkir dan lewat di atas trotoar seenaknya. Dan yang terutama, terdapat sebuah action, sebuah aksi atau kegiatan. Sepanjang jalan dipenuhi dengan toko-toko atau department store dan warung-warung yang memicu adanya kegiatan ekonomi di daerah tersebut. 
Pedestrian Jalan Tunjungan mengalami degradasi dari baik space, movement, dan khususnya action. Dari segi space telah dibahas sebelumnya, bahwa bentukan dan dimensi arcade-arcade yang sekarang sudah tidak memenuhi lagi. Dari segi movement, diabaikannya faktor safety, convenience, dan pleasure, seperti yang telah dibahas di dua point sebelumnya, meminimumkan movement pejalan kaki. Action, elemen yang ketiga dan mungkin yang terpenting karena mengubah pedestrian menjadi bukan instrument sirkulasi biasa, juga mengalami penurunan yang signifikan dibandingkan abad 20 lalu. Suatu interaksi sosial maupun kegiatan ekonomi akan sangat jarang atau bahkan tidak mungkin terjadi di Jalan Tunjungan.

Secara luas, Jalan Tunjungan yang harus juga dimanfaatkan sebagai action ini hendaknya dapat membangkitkan budaya melalui event-eventnya. Pada abad 20an, Jalan Tunjungan dilalui banyak marching band pada saat Carnaval. Lebih jauh lagi, jalan ini juga dilalui barisan marinir yang menuju ke Jalan Simpang. Event menarik lainnya pada adalah Parade Juang yang memparodikan perjuangan arek-arek Suro-boyo di Hotel Majapahit melawan Belanda.

Kini, Walikota Surabaya Ibu Tri Risma telah membangkitkan event ini melalui Parade Bunga, Surabaya Urban Culture Festival, dan Car-free day. Suara Surabaya juga mengadakan event seperti Remong Masal. Pelaksanaan event seperti inilah yang membangkitkan Jalan Tunjungan ke kejayaannya yang semula (Gambar 13).

Hendaknya event seperti ini diadakan secara berkala dan berkelanjutan. Sebagai contoh, pada harihari raya misalnya pada saat Idul Fitri diadakan Parade Bedug ketika Takbiran, atau Parade Barongsai (yang telah mengalami akulturasi antara budaya Tionghoa dan Jawa) pada saat Tahun Baru China.

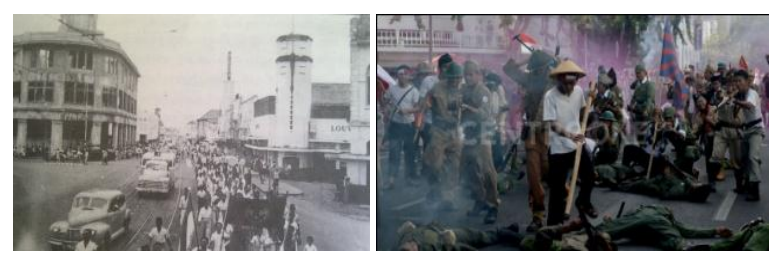

Gambar 12. Event Tempo Dulu di Jalan Tunjungan

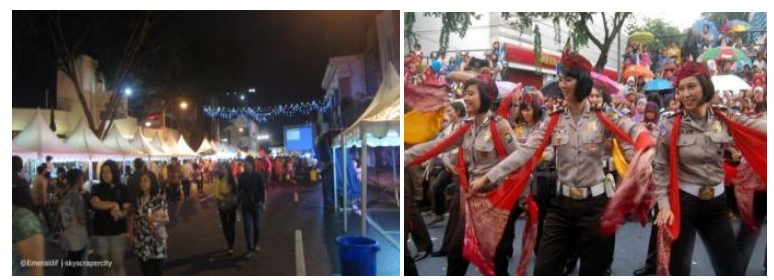

Gambar 13. Event di Jalan Tunjungan Sekarang

\section{Bridges and Elevated Streets}

Jika jembatan layang di Jalan Tunjungan langsung dinilai berdasarkan pemikiran Untermann bahwa overpass sangat tidak mendukung suatu pedestrian, maka boleh dikatakan bahwa jembatan layang ini harus disingkirkan, seperti keadaan Jalan Tunjungan pada zaman pra-kemerdekaan.

Jembatan layang ini, dari segi kesejarahan, memiliki nilai yang sangat tinggi. Pembangunan jembatan dua tingkat yang kemudian difungsikan sebagai toko yang menyatukan antara Siola dan department store di seberangnya, Aurora, merupakan hal baru dan membanggakan bagi Surabaya. Pejalan kaki yang menyeberang dapat sekaligus menikmati toko-toko di dalamnya dan bahkan membeli barang di sana. Bisa dibayangkan betapa menyenangkan, khususnya bagi anak-anak, untuk menyeberang dengan jembatan layang ini, kemudian melihat-lihat orang-orang berjualan di dalamnya dan memandang ke bawah ke arah jalan raya lewat jendela-jendelanya. Jembatan itu kini telah mati. Bukan hanya mati karena tidak ada orang yang mau melaluinya, tetapi juga karena jembatan tersebut ditutup. Padahal, jembatan tersebut memegang peranan penting. Menurut hasil wawancara dengan generasi sebelumnya, dahulu pernah ada kecelakaan yang menewaskan satu keluarga yang nekat menyeberang tanpa menggunakan jembatan. Akibatnya, deparment store Aurora yang berada di ujung akhir jembatan menjadi sangat sepi, mengingat warga Surabaya sangat percaya takhayul dan nasib buruk.

Salah satu alasan matinya toko-toko di dalam jembatan adalah karena pemasangan billboard besar. Pemasangan ini sebenarnya merupakan suatu kebanggaan juga dimana billboard ini digunakan untuk menayangkan film-film. Tetapi, kurangnya perhatian terhadap aktivitas di dalam jembatan tersebut akhirnya mematikan jembatan itu sendiri. Cahaya matahari tidak dapat masuk ke dalam jembatan itu dan mengakibatkan suasana yang suram, tertutup, dan terhimpit. Akhirnya, orang akan merasa tidak nyaman dan takut melewatinya. Inilah yang menyebabkan matinya jembatan tersebut.

\section{The Care and Feeding of The Pedestrian}

Hanya ada dua restoran di Jalan Tunjungan. Pertama, Restoran Oikos yang menjual makananmakanan Italia, lengkap dengan kursi-kursi di luar (outdoor). Kedua, restoran di dalam toko pusat oleholeh 'Wisata Rasa'. Yang kedua ini pun letaknya sangat jauh di dalam, terpisah dari pedestrian oleh lapangan parkir yang luas dan tidak mengizinkan 
adanya kontak dengan pedestrian. Tempat-tempat berjual-an makanan yang lain lebih berupa tenda atau vendor-vendor yang kurang terawat dan malah memberi kesan kumuh. Pujasera di TC dan TEC tidak dapat dimasukkan dalam kategori ini, karena letaknya yang sudah begitu jauh dan tidak terjangkau oleh pejalan kaki. Di TEC, misalnya, pujasera berada di lantai basement. Untuk sebuah kawasan sepanjang kurang lebih satu kilometer, perlu dipertimbangkan lagi apakah dua restoran ini, Oikos dan Wisata Rasa, sudah memadai untuk pejalan kaki.

Namun, banyak restoran saja tidak cukup. Restoran yang banyak tetapi tidak dapat mendorong kegiatan ekonomi tidak akan bisa dinikmati. Misalnya di TC, yang menjadi penarik perhatian adalah gambar-gambar makanan yang ditempel di jendela pujasera. Pejalan kaki akan mudah jemu hanya melihat gambar-gambar saja, tetapi tidak dapat melihat bagaimana koki-koki dengan handal memasak, atau melihat bagaimana pengunjung menyantap masakannya dengan lahap sehingga tidak tertarik membeli. Dibandingkan dengan gambar-gambar mati, tentunya action dari koki maupun konsumen yang diperlihatkan pasti akan memancing keingintahuan pejalan kaki untuk mencoba, yang pada berujung pada kegiatan ekonomi. Dan kegiatan ekonomi ini sendiri dapat mencegah terjadinya kriminalitas.

Selain berhubungan dengan tempat makan, keberadaan vendor-vendor atau penjaja keliling yang menjual minuman maupun makanan ringan sangat diperlukan. Perlu diingat agar vendor-vendor ini tampil cantik dan atraktif, tidak kumuh seperti sekarang. Ketiadaan check-in juga memberikan ketidaknyaman-an lain bagi pengunjung yang membawa banyak barang bawaan. Sering pengunjung harus bolak-balik ke kendaraan mereka untuk memasukkan barang jika tidak mau menentengnya selama berjalan. Harus diakui bahwa pedestrian Jalan Tunjungan sangat tidak ramah dengan pejalan kaki di dalamnya karena kurangnya fasilitas umum seperti street furniture seperti kursi taman untuk pejalan kaki yang lelah karena perjalan panjang, tong sampah, potpot tananam yang dapat difungsikan untuk dudukduduk, dan pepohonan sebagai peneduh.
Intinya, pedestrian Jalan Tunjungan disediakan untuk pejalan kaki. Maka, tidak cukup jika para pejalan kaki hanya diberi sebuah jalan tempat mereka dapat berlalu lalang untuk mencapai tujuan, tetapi juga harus difasilitasi sedemikian hingga pejalan kaki dapat terpenuhi segala kebutuhannya.

\section{Crime Does Pay}

Masalah kriminalitas yang akan disorot dalam studi ini adalah vandalisme, fenomena yang sudah tidak asing bagi warga Surabaya. Setiap ada tempat yang sudah tidak terpakai, pasti akan ada orang-orang tidak bertanggung jawab yang merusaknya. Setiap kali ada sebuah benda, properti, atau fasilitas umum yang tidak ada yang merasa memilikinya, berarti benda tersebut siap untuk menjadi korban vandalisme. Di Jalan Tunjungan, bangunan-bangunan yang sudah tidak terpakai dikotori dinding-dindingnya dengan grafiti (Gambar 14).

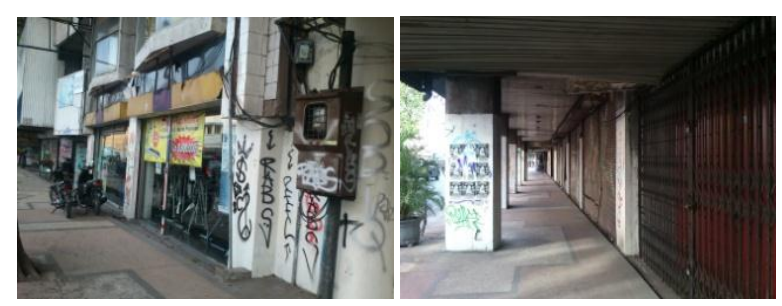

Gambar 14. Grafiti pada Dinding dan Kolom Bangunan Sepanjang Arcade Pedestrian Jalan Tujungan

Untuk poin yang terakhir ini, sebenarnya tidak ada suatu penyelesaian atau pemikiran yang dapat menyelesaikan kriminaliatas dari segi arsitektur dalam suatu pedestrian.

Sebaliknya, sekali lagi mengutip perkataan Untermann, bahwa pejalan kaki-lah yang dapat sadar pada kehadiran orang-orang luar dan mendeteksi keanehan seperti vandalisme, perampokan, dan penjabalan. Semisalkan kelima elemen di atas sudah mendapatkan sebuah improvisasi sehingga pedestrian Jalan Tunjungan dapat dipenuhi dengan pejalan kaki yang merasa memiliki jalan ini, maka masalah kriminalitas dengan sendirinya akan teratasi.

Rangkuman seluruh hasil data penelitian analisa dan pendapat dapat di lihat di Tabel 1. 
Tabel 1. Hasil Analisa Pedestrian Jalan Tunjungan

\begin{tabular}{|c|c|c|c|c|}
\hline ELEMEN & $\begin{array}{c}\text { DATA TUNJUNGAN } \\
\text { ABAD } 20\end{array}$ & $\begin{array}{c}\text { DATA TUNJUNGAN } \\
\text { ABAD } 21\end{array}$ & ANALISA & HASIL \& SOLUSI \\
\hline Street for pigs. & $\begin{array}{l}\text { Pedestrian lebih sempit, } \\
\text { view jalan Tunjungan la- } \\
\text { pang, desain bangunan } \\
\text { detail untuk pejalan kaki. }\end{array}$ & $\begin{array}{l}\text { Pedestrian lebih lebar, view } \\
\text { jalan Tunjungan banyak ter- } \\
\text { halang bilboard, desain } \\
\text { Terfokus ke kendaraan. }\end{array}$ & $\begin{array}{l}\text { Kurangnya aspek pleasure. View } \\
\text { ke jalan Tunjungan terhalang. } \\
\text { Pedestrian terabaikan. }\end{array}$ & $\begin{array}{l}\text { Tampak bangunan diper- } \\
\text { baik. Fungsi pedestrian di } \\
\text { rehabilitasi sehingga nilai } \\
\text { pleasure timbul. }\end{array}$ \\
\hline $\begin{array}{l}\text { The Canopied } \\
\text { streets. }\end{array}$ & $\begin{array}{l}\text { Vertikal: langit-langit lebih } \\
\text { tinggi. Horisontal: pene- } \\
\text { duhan dengan kanopi } \\
\text { tanpa kolom. }\end{array}$ & $\begin{array}{l}\text { Vertikal: langit-langit rendah. } \\
\text { Horisontal: kolom-kolom be- } \\
\text { sar berjejer disepanjang pe- } \\
\text { destrian. }\end{array}$ & $\begin{array}{l}\text { Secara vertikal, pedestrian abad } \\
21 \text { memberi kesan suram. Secara } \\
\text { horisontal, tidak memberi space } \\
\text { cukup. }\end{array}$ & $\begin{array}{l}\text { Pedestrian diperlebar. } \\
\text { Kolom-kolom di fungsikan } \\
\text { untuk membangkan nilai } \\
\text { budaya. }\end{array}$ \\
\hline $\begin{array}{l}\text { The Street } \\
\text { Where the } \\
\text { Action is }\end{array}$ & $\begin{array}{l}\text { Event: Parade Surabaya } \\
\text { Juang, Barisan Marinir, } \\
\text { Marching band } \\
\text { (Carnaval). }\end{array}$ & $\begin{array}{l}\text { Event: Surabaya Urban } \\
\text { Culture Festival. Parade } \\
\text { bunga, Remong Massal SS. }\end{array}$ & $\begin{array}{l}\text { Jalan Tunjungan abad } 21 \text { memi- } \\
\text { liki potensi event. Dimulai dari } \\
\text { Car free day. }\end{array}$ & $\begin{array}{l}\text { Pemanfaatan pada car } \\
\text { free day. Penambahan } \\
\text { Event besar pada hari } \\
\text { besar agama. }\end{array}$ \\
\hline $\begin{array}{l}\text { Bridge and } \\
\text { Elevated } \\
\text { Streets }\end{array}$ & $\begin{array}{l}\text { Jembatan penyebrangan } \\
\text { tanpa Bilboard. }\end{array}$ & $\begin{array}{l}\text { Jembatan penyebrangan } \\
\text { Tertutup Bilboard. }\end{array}$ & $\begin{array}{l}\text { Bilboard menghalangi cahaya } \\
\text { matahari, mengurangi intensitas } \\
\text { daylighting. }\end{array}$ & $\begin{array}{l}\text { Penempatan Bilboard } \\
\text { memerlukan desain } \\
\text { Khusus. }\end{array}$ \\
\hline $\begin{array}{l}\text { The Care \& } \\
\text { Feeding of } \\
\text { Pedestrian }\end{array}$ & $\begin{array}{l}\text { Tersedia berbagai dept. } \\
\text { store, restoran, vendor- } \\
\text { vendor dan penjaja } \\
\text { keliling. }\end{array}$ & $\begin{array}{l}\text { Kurangnya restoran. Vendor } \\
\text { dan penjaja keliling kelihatan } \\
\text { kumuh. }\end{array}$ & $\begin{array}{l}\text { Kurangnya fasilitas pendukung } \\
\text { pedestrian sehingga membuat } \\
\text { pemakai pedestrian cepat berlalu } \\
\text { dari jalan Tunjungan. }\end{array}$ & $\begin{array}{l}\text { Penambahan restoran } \\
\text { (pada bangunan kosong). } \\
\text { Pemeliharaan vendor \% } \\
\text { PK5. }\end{array}$ \\
\hline $\begin{array}{l}\text { Crime Does } \\
\text { Pay }\end{array}$ & Tidak ada vandalisme. & Terjadi vandalisme. & $\begin{array}{l}\text { Kurangnya pemanfaatan } \\
\text { pedestrian sehingga timbul } \\
\text { vandalisme. }\end{array}$ & $\begin{array}{l}\text { Memperbaiki } 5 \text { elemen } \\
\text { di atas. }\end{array}$ \\
\hline
\end{tabular}

\section{KESIMPULAN}

Jalan Tunjungan telah mengalami degradasi dibanding abad sebelumnya. Degradasi ini didorong oleh penambahan kendaraan ber-motor serta tidak memadainya pedestrian untuk pejalan kaki. Hal ini mempengaruhi faktor-faktor seperti estetika, sosial, ekono-mi, dan kriminalitas sehingga jadilah Jalan Tunjungan yang tidak lagi bisa dipakai 'mlaku-mlaku nang Tunjungan' di abad 21.

Untuk itu, usulan yang diberikan dalam rangka mengembalikan 'mlaku-mlaku nang Tunjungan' demi menjadikan Tunjungan sebagai tempat rekreasi yang memiliki nilau kultural dan historis, beberapa hal yang dapat dilakukan adalah sebagai berikut:

- Perlebaran pedestrian dengan mengambil jalur parkir mobil guna memberikan kenyamanan lebih pada pejalan kaki dan membatasi jumlah kendaraan bermotor yang masuk ke Jalan Tunjungan.

- Penanaman pohon dan penambahan kursi taman untuk mengembalikan nilai kultural dan sosial bagi warga Surabaya.

- Pencopotan billboard pada jembatan penyebrangan guna menghidupkan lagi.

- Pemanjangan pulau jalan pada pertigaan jalan Genteng Besar untuk memperlambat laju mobil dari arah Jalan Tunjungan.
- Penambahan jembatan penyebrangan pada pertigaan jalan Genteng Besar yang menyambung dengan bangunan.

- Penambahan dan perbaikan vendor pada pedestrian di kedua sisi.

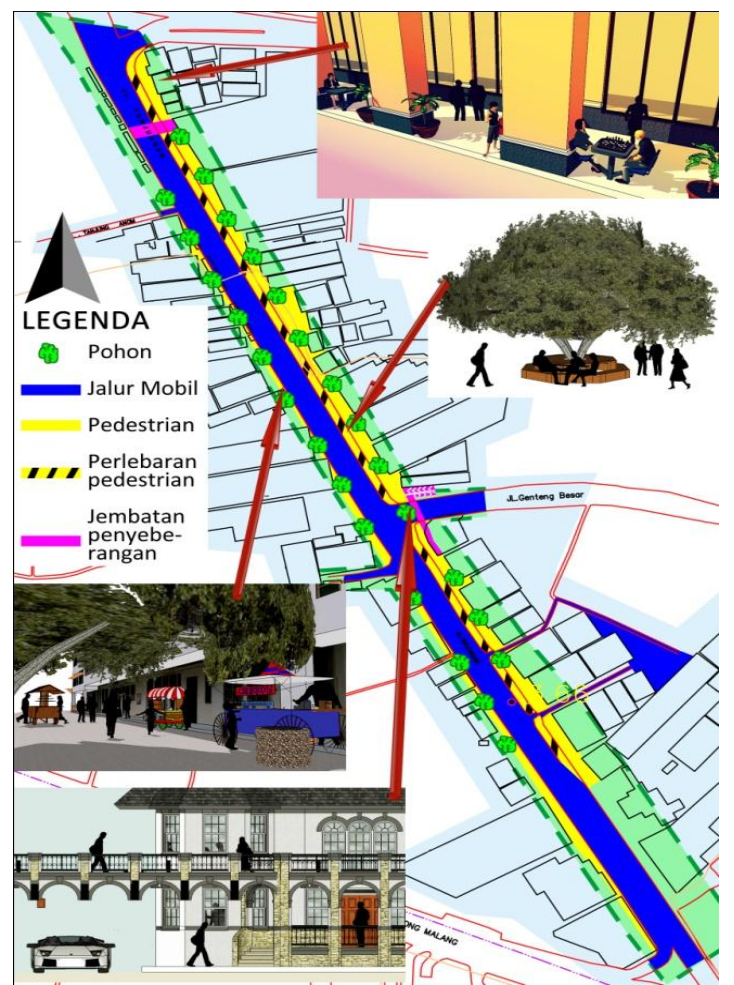


- Pemanfaatan kolom-kolom raksasa di daerah Tunjungan Center untuk tempat sosialisasi, misalnya dengan tempat duduk-duduk bermain catur atau permainan tertentu yang kaya budaya.

- Penggunaan lahan kosong di belakang area ruko sebagai parkiran baru mobil.

- Pemanfaatan bangunan kosong sebagai restoran, toko, dan check-in point.

- Pengadaan event-event seperti Car-free day dan Surabaya Urban Culture Festival secara lebih berkala di Jalan Tunjungan. Bisa juga ditambah dengan parade hari-hari raya lainnya.

- Jalan Tunjungan digunakan sebagai rute marching band, atau kegiatan-kegiatan karnaval lainnya.

Untuk kedepannya, perlu diadakan suatu penelitian lebih lanjut dengan skala yang lebih luas, misalnya mengkaji cangkupan yang lebih luas mulai dari sepanjang Jalan Pahlawan, Jalan Gemblongan, Jalan Tunjungan, dan jalan Guberur Suryo hingga pangkal Jalan Pemuda di depan Hotel Sahid.

\section{DAFTAR PUSTAKA}

Adorno, Theodore W. (2004). "Culture Industry Reconsidered." The City Cultures Reader: 163168.

Day, Kristen, et al. (2007). "Remaking Minnie Street: The Impacts of Urban Revitalization on Crime and Pedestrian Safety." Journal of Planning Education and Research, 3, 315. 26 Okt 2013 $<$ http://jpe.sagepub.com/cgi/content/abstract/ 26/ $3 / 315>$

Dodd, Dianne (2004). "Barcelona: The Making of a Cultural City." The City Cultures Reader: 177182.

Fridman, Natalie, Avishy Zilka, dan Gal A. Kaminka (2011). "The Impact of Cultural Differences on Crowd Dynamics in Pedestrian and Evacuation Domains." 26 Okt 2013. <http://u.cs.biu.ac.il/ $\sim$ galk/ Publications/Papers/culture11tech.pdf>

Griffin, Em. "A First Look at Communication Theory." A First Look. McGraw-Hill. 13 November $2013<$ http://www.afirstlook.com/ docs/proxemic.pdf>

Rudofsky, Bernard. (1982). Streets for People. New York: Van Nostrand Reinhold Company Inc.

Silas, Johan (1984). "Penutupan Jalan Tujungan Butuh Pandangan Optimis." Surabaya Post 21 November.

Soenarjo, H., \& Aminuddin Kasdi (2006). Mana Soerabaya Koe. Surabaya: Pustaka Eureka.

Untermann, Richard K. (1984). Accomodating the Pedestrian. New York: Van Nostrand Reinhold Company Inc.

Urry, John. (2004). "Reinterpreting Local Culture." The City Cultures Reader: 169-176 "Menutup Jalan Tunjungan, Mendatangkan Bajaj?" Surabaya Post 7 November 1994. 